\title{
Interaction of cyanine dyes with nucleic acids. 6. Synthesis and spectroscopic properties of thiazole orange-amino acids conjugates
}

\author{
Siergiy M. Yarmoluk, Dnnytro V. Kryvorotenko, Yuriy S. Gerasymchuk
}

Institule of Molecular Biology and Genetics, Natiorial Academy of Sciences of Ukraine 150 Acrid. Zkibolotnoho vul., Kyiv, 252143, Ukrain!?

\begin{abstract}
The whthesis of umino acid (L-Trp and L-Tyr) derivatives of thiazole orange, monomethine cyanine dye which significantly increases fluorescence intensity when bound to nucleic acids is described. Hydraxysuccinimide ester of Cyan 6 (2-[4-N-Carboxyethyl-quinoline)-methyl]-3-methylberithiazole-1,4(p-toluenesulfonat, ) was used for the conjugation of dye with amino acids. Interaction of ootained conjugater with nucleic acids was investigated using spectroscopic methods.
\end{abstract}

Materials and Methods. The TLC was performed on Kitselgel $60 \mathrm{~F}_{254}$ plates («Mlercks, Germany) using C. $\mathrm{HCl}$ - $\mathrm{MeOH}-\mathrm{AcOH}$ (8.5:1.0:0.5) sysiem. FAB MS andyses were carried out in the positiva mode using mass spectrometer MI-1201E (PD «Elıktron», Ukraine).

Spectroscopic measurements. "The absorption spectra were: recordsed on \&Specord M-40. (VEB Carl Zeiss Jelli, Gornany). Fluorescence spectra were obrained with fluorescence spectrcphotorneter Hitachi Mcdel 850 (Japan), Fluorescence was excited with 150W Xe-lamp emission and measurements were carried out in thermostatable quartz cell $(0.5 \times$ $\times(1.5 \mathrm{~cm})$. All spectra were corrected b; multiplying flursescence intensities measured over an interval of 5 lim by proper correction factor for corresponding warelengtkıs. In corrected spectra flucrescence intensily values were prop :tional to a numbers of photcris per unit of wavelenglit interval.

preparation of DNA, RNA and dyes stock solutiains. Stcck solutions of dyes $\left(2 \cdot 10^{-3} \mathrm{M}\right)$ were prepared by dissolving dyes in DMSO. All dyes were stable urider these conditions for several months, whereas in aqueous solutions some dyes gradually lost their fluorescence properties. Working solutions were prepared immediately prior to use. For spectral studies tcital calf thymus DNA («Sigma») and yeast RNA (C)
YII. S. TARMOLUK, D. V. VRASYMCHUK,
1999
( Sigma») were used. Nucleic acids stock solutions were prepared in TE buffer (Tris-HCl, $50 \mathrm{mM}$, EDTA, $10 \mathrm{mM}, \mathrm{pH} 8.0$ ) in concentration $6 \cdot 10^{-3} \mathrm{~b}$. p./ml for DNA and $1.2 \cdot 10^{-2}$ b. p./ml for RNA.

Absorbance and fluorescent emission spectra. For spectral measurements the complexes of dyes with nucleic acids were obtained in Tris- $\mathrm{HCl}(50 \mathrm{mM}, \mathrm{pH}$ 8.0) buffer by mixing of dye stock solution with DNA or RNA solution. The final concentration of NA was $10^{-4}$ and $2.0 \cdot 10^{-4} \mathrm{mM}$ respectively. Final dyes concentrations were $0.02 \mathrm{mM}$. Dye-nucleic acid complexes were prepared with approxymal ratio 1 dye per 20 b. p. of RNA and per 10 b. p. of DNA. For optical measurement of free cyanines the same dyes concentrations were used.

Fluorescence titration o, Cyan 6-Trp and Cyan $6-T y r$ were carried out in $0.05 \mathrm{M}$ Tris buffer ( $\mathrm{pH} 8$ ) with total calf thymus DN'A and yeast RNA at $540 \mathrm{~nm}$ for DNA and $545 \mathrm{~nm}$ for RNA. Fixed concentration of DNA $6 \cdot 10^{-3} \mathrm{~N}$ and $1.2 \cdot 10^{-2} \mathrm{M}$ were used for the titration of fixed zoncentration of dye ( Fig. 3). The dye concentration was $10^{-5} \mathrm{M}$. The DNA and RNA concentration was char ged from $2.5 \cdot 10^{-0}$ to $10^{-4}$ from $5 \cdot 10^{-6}$ to $2 \cdot 10^{-4}$ respectively.

General procedure for the synt.hesis cyanine dyeamino acids conjugates. The succinimidyl ester of Cyan 6 was prepared by dissolving th' dye $(5.34 \mathrm{mg}$, $0.01 \mathrm{mmol}$ ) in $1 \mathrm{ml}$ of dry DMFA as' then adding $\mathrm{N}$-hydroxysuccinimide $\left(1.15 \mathrm{mg}, 0.0^{\prime} \mathrm{mmol}\right)$ and 


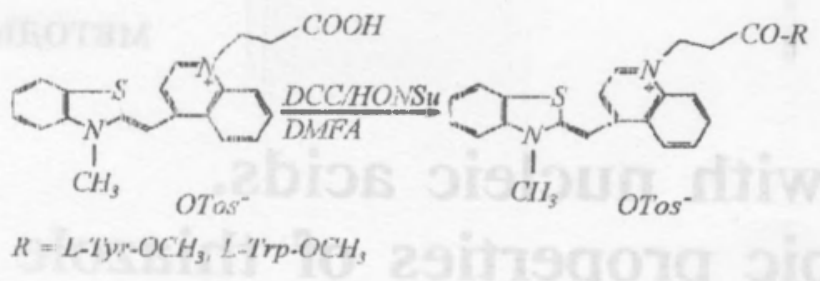

Fig: 1. Syntlietic scheme of preparation of dye-amino acid conjug,il tes:

[NCC (4.12 $\mathrm{mg}, 0.02 \mathrm{mmol}$ ) to stirred sol ition at $0{ }^{\circ} \mathrm{C}$. Misture was stirsed for $4 \mathrm{~h}$. Then amino acid ester hytrochloride $(0.011 \mathrm{mM})$ and $0.05 \mathrm{ml}$ of dry pyridire were added. Reaction mixlure was stirred for $2 \mathrm{~h}$ at $0{ }^{\circ} \mathrm{C}$ and was kept in refrigerator for $18 \mathrm{~h}$. Purification of atnino acid-Cyan 6 conjugates was petformed on the prepared C3 stationary phase [1]. Conjugatesi were recovered from the fractions with a rotary evaporator at $40^{\circ} \mathrm{C}$.

Cyan 6-Trpm-OCH3. $\mathrm{R}_{f}=0.67 \mathrm{MS}: \mathrm{m} / \mathrm{e}$ (relative intensity) $563(\mathrm{MH}+, 5), 363(14,, 317(3), 290(6)$, $27,3(5), 254(4), 219(4), 150$ (15).

Cyan 5-Tyr-OCH3. $\mathrm{R}_{f}=0.72 \mathrm{MS}: \mathrm{n} / \mathrm{e}$ (relative inten.sity) $540(\mathrm{MH}+, 14), 526(6), 407(7), 363(27)$, $317(7), 303(7), 290(12), 275$ (9), 219 (6), 150 (18i).

Results and Discussion. The cyanine monomethine dyes have many of properties presented as ideal for the fluorescent homogeneous detection of nucleic acids. With this determination principle no separation of unbound probe: is necessary [2]. A series of new mononeric: and dimeric fluorescent cy'anines have recently teen developed for this purpose $[3,4]$. Mc nornethine cyanine dyes seem to pos:ess all characteristics for quantitation of unknow nucleic acids in solutions, as low intrinsic fluorescence of unbound probe, large fluorescence enhancement upon probe binding, large linear detection range, and sequence non-specific cletection [5 I.

The main research of our laboratory concerns development of scquence specific homogeneous detecticin of nucleic acids in solution. Recently pyrylium cyanine dy'e --- oligonucleotide conjugate was used for the detection of specific DNA sequences [6]. Here we describe the preparation of cyanire dye-amino acid corljugates for the potential fluorescence sequence specific determination of nuclcic acids in solution.

Ehefore some synthetic procedures for the covalent labelling of biomolecules with cyanine: dyes were described by Waggoner et al. 17]. Functional groups in proposed cyanine reagents were sulfhydryl [7], isothiocyanate [8] and succinimidyl esters [9]. Procedure using active $\mathrm{N}$-hydroxysuccinimide esters of dye seems to be more convenient for their conjugation with $\alpha$-amino group of amino acids or peptides. Besides we have shown recently that incorperation of carboxylic acids groups in to basic cyanine structure of TO did not influence on fluorescence probe properties [10] (Fig. 1).

Succinimidyl ester of dye carboxyl group and methyl esters of hydrochlorides of amino acids in pyridine were used to synthesize amino acid-dye conjugates. Active esters were prepared with use the DCC and hydroxysuccinimide (HONSu) in DMFA.

Recently published methods for the HPLC of cyanine dyes use $C_{18}$ stationary phase 111\%. Unfortunately, used cyanine dyes are very hydiophobic and positively charged compounds. As a result, they have large retention time on HPLC stationary phases. In order to overcome these problems TMS-sjlica $\left(C_{3}\right)$ stationary phase prepared according to [1] was successfully used (Fig. 2). Chemical structures of synthesized conjugates were confirmed by fast atom bombardment mass spectrometric (FAB MS) analyses.

Spectroscopic data for two synthesized cyanine conjugates and Cyan 6 (TO analog) are presented in Table. 1. Dye Cyan 6 with previously investigeted spectral properties was included for the comparison [9]. Absorption spectra of Cyan 6 an its amino acid

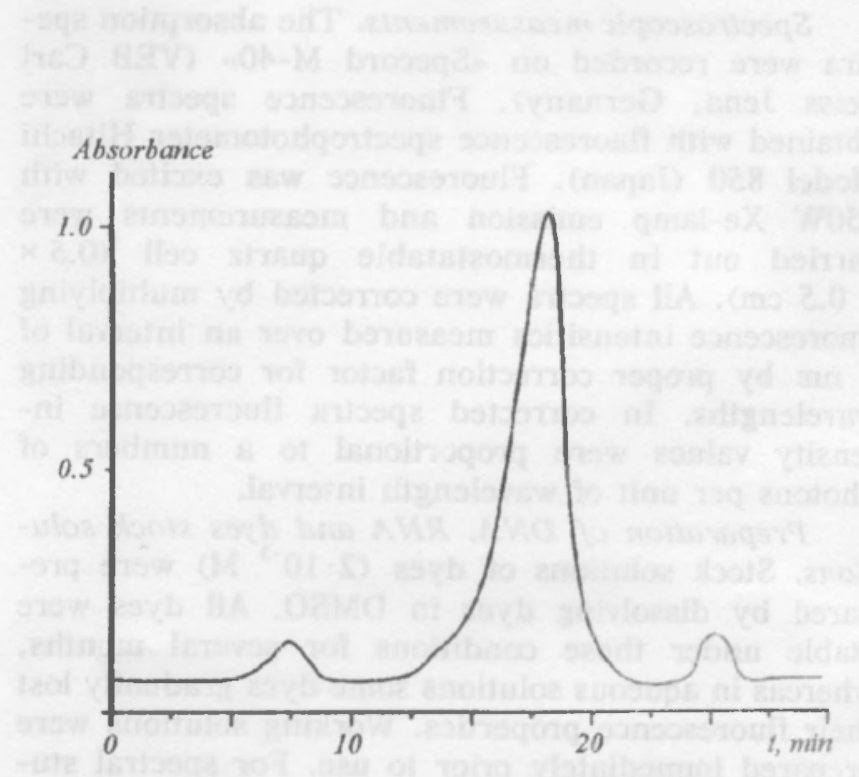

Fig. 2. Chromatogran of reaction mixture of cyanine dye conjugation with L-Trp using $C_{3}$ stationary phase. Mobile phase: buffer $A$ $0.05 \%$ TFA, buffer $80 \%$ dioxan. Flow-rate: $5.0 \mathrm{~m} 1 / \mathrm{min} ; \lambda=506$ 
Table I

Chemical structures arld spectroscopic properties of cyanine dyes
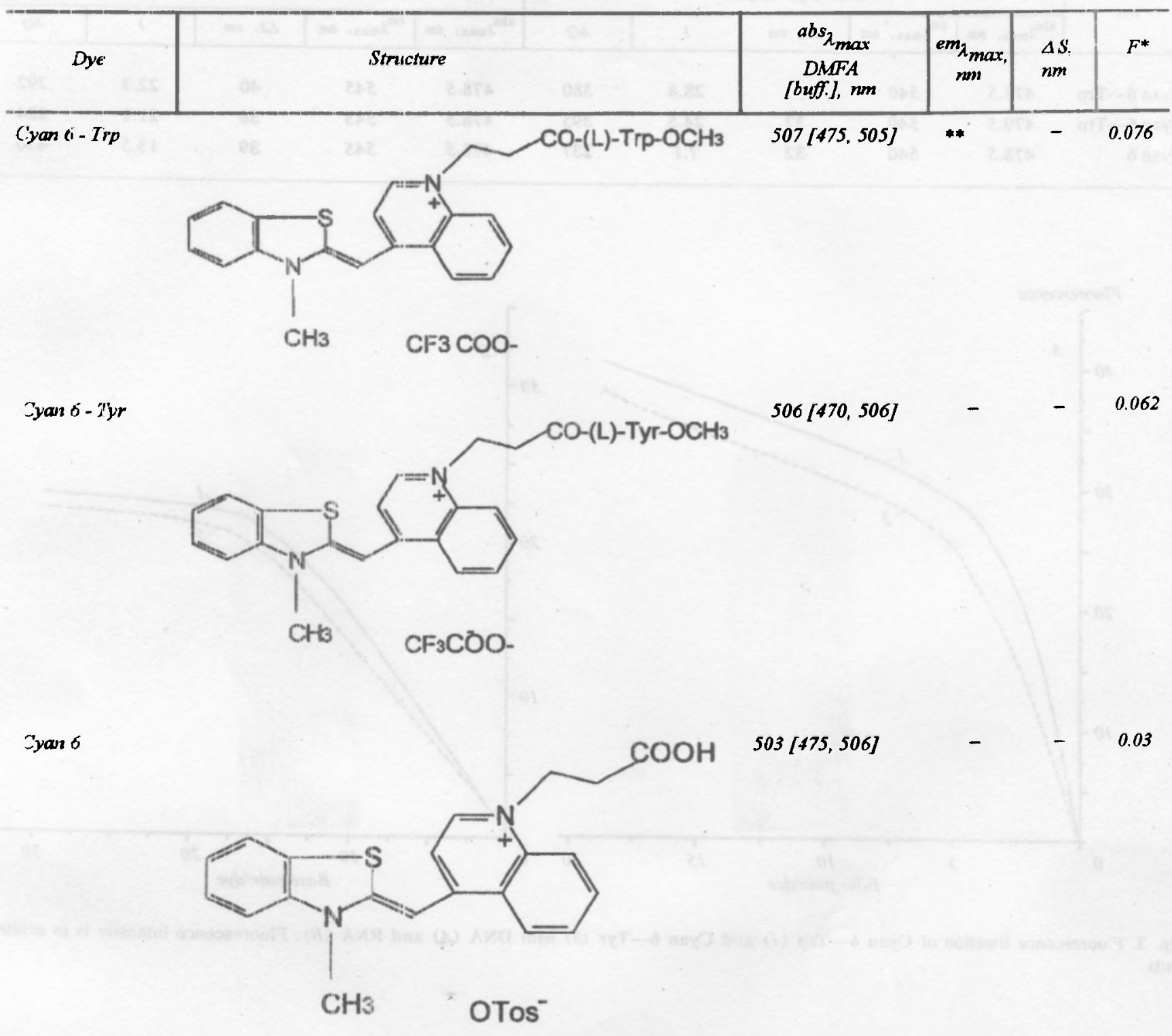

*Arbitrarv units; **There is no clear maxima.

derivatives were similar. The wavelengths of absorption maxima $\left({ }^{a b s} \lambda_{\text {max }}\right)$ of Cyan 6-T $\mathrm{p}$ and Cyan 6-.-Tyr slightly depended on solvent. Cyanine dyes showed the red shift $(5--7 \mathrm{~nm}$ ) after going from aquecus buffer to less polar DMSO.
The fluorescence of conjugates and free Cyan 6 were very low and fluorescence spectra had no clear maxima. Fluorescence intensity of aunino acids derivatives were slightly higher as com, raied to free dye.

The data on the absorbance in: fluorescence 
knowledge the assistance of Ms. Vladislava Kovalska in spectral characterisation of dye-amino acid conjugates. We thank Dr. Yury Kovtun for providing us with the sample of cyanine dye Cyan 6 .

\section{С. М. Урмолюк, Д. А. Криворопиенко, К. С. Герасимиук}

Взавмодія ціанынових барвників з нуклеіновими кислотами. 6. Сиятез та ситектроскопічні втастивості кон'югитів тізолового орицже вого : амінокнслотами

Резьоме

Oniscarj синтеs амінокистотних похідних (L-j'rp ma L-Tyr) з тігзоливиж: оранжевим - монометиновьм цціаніновим барвни-

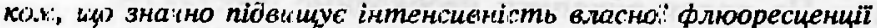
при зв язузинні з нуклеїновики кислстали. Гірроксисукци-

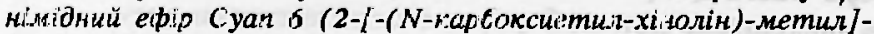
3-лнетилбеікітікзол-1,4-n-толулолсу-гьфіта) бірв выкориста-

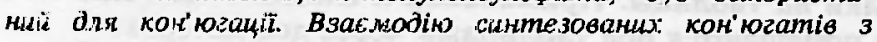

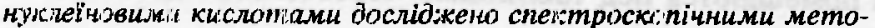
$\partial a r \cdot u$.

\section{С. А. Ярмолюк, Д. в․ Кризоропенко, К. С. Герасимиук}

Взанмдейстане цианиновых красиาелей с нукјеиновыми кислотами. 6. Сингез и спектроскопикеские свойсгва конъюгатов тия жоловоп оранжевого $\approx$ аминокис.лотами

Peis:ome

Onıсач синтез аминокислотных произеэднех (L-Trp и L-Tyr) с mиц оловьм оранжевым - монометиновым цианиновым красиніелея, которий значитольно учеличивиет интенсив-

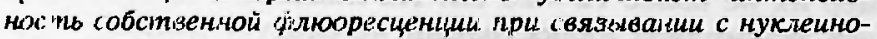

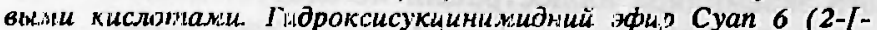
(N-картіксизтил-хинолин)-метил]-3-метилбен: зтиазол-1,4 $n$ толулолсульрапа) был использован аля контюгпции красителя с сниныкислотами. взаимодейстєие синтезированных конъюганде с нукетеиновыни кислотами цсследовано спектроскопинескини ме'

\section{REJERJENCES}

1. Ксслашников В. В., Самуков В. А, Шубин: Т. Н. Использэзание обраценно-фазовой хроматографии в олигонуклеотидном синтезе // Бияоорг. химия.-1983.-9.C. $666-\cdots 672$.
2. Schwartz H. E., Ulfelder $K$ J. Capillary electrophoresis with laser-induced fluorescence detection of PCR fragments using thiazole orange // Anal, Chem.-1992.-64, N 15.P. $1737-1740$.

3. Haughland $\boldsymbol{R}$. $\boldsymbol{P}$. Handbook of fluorescent probes and research chemicals // Molecular Probes.-Eugene: OR, 1996.-679 p.

4. Yarmoluk S. M., Kovalska V. B., Smirnova T. V., Shandura

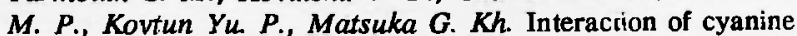
dyes with nucleic acids. 2. Spectroscopic properties of methyleneoxy analogues of thiazole orange // Biopolimery i kletka.1996.-12, N 6.-P. P. 74-81.

5. Skeidsvoll J., Ueland P. M. Analysis of double-stranded DNA by capillary electrophoresis with laser-induced fluorescence detection using the mononeric dye SYBR Green I // Anal. Biochem.-1995.-231-P. 359-365.

6. Yarmoluk S. M., Kostenko A. M., Kornushyna O. S., Dubey' I. $Y$. Interaction of cyanine dyes with nucleic acids. 4. Efficient 5 '-fluorescent labelling of oligonucleotides with monomethyne pyrylium cyanine dye, Cyan 39 // Biopolimery i kletka.1998.-14, N 1.-P. 82-86.

7. Ernst L A., Gupta R. K., MuJumdar R. B., Waggoner A. S. Cyanine dye labelling reagents for sulfhydryl groups // Cy tometry.-1989.-10.-P. 3-10.

8. Mujumdar R. B., Ernst L. A., Mujumdar S. R., Waggoner A. $S$. Cyanine dye labelling reagents containing isothiocyanate groups // Cytometry.-1989.-10.-P. 11-19.

9. Southwick P. L., Ernst L A., Tauriello E. W., Stephen R. P., Mujumbar R. B., Mujumbar S. R., Clever U. A., Waggoner A. $S$. Cyanine dye labelling reagents - carboxymethylindocyanine succinimidyl esters // Cytometry.-1990.-11.-P. 418430.

10. Yarmoluk S. M., Zhyvoloup A. N., Koval'ska, Klimenko I. V., Slomisky $Y u$. $L$. Interaction of cyanine dyes with nucleic acids. I. Studies on monomethyne cyanine dyes as possible fluorescent probes for the detection of nucleic acids // Biopolimery i kietka. -1996. -12.-P. 69-74.

11. Akins D. L, Kuinar V. T. High performance liquid chromatography of cyanine dyes Multipuase separation, purification, and substitution of the counter ion // J. Chrom. A.-1995.-689.P. 269-273. 